\title{
Pengembangan Tata Kelola TI Untuk Menunjang Kegiatan Bisnis Pada Universitas (Studi Kasus Universitas Merdeka Madiun)
}

\author{
Arief Budiman \\ Fakultas Teknik,Universitas Merdeka Madiun \\ Jl. Serayu Tromol Pos 12 Madiun 63133 \\ Email : arief@unmer-madiun.ac.id
}

\begin{abstract}
Development of IT Governance to Support Business Activities on University (Case Study: Merdeka Madiun University). Currently, the use of information technology (it) has become one of the supporting organization's success, but if your organization does not have good control of it, it will only burden or new problems in the organization. Therefore, we need good governance to overcome the gap between the description of the recommended system with the necessary description for the actual system implementation. And to measure the extent to which IT alignment with business activities and measure the extent to which maturity level an organization can be done by using the COBIT framework. Therefore we need a IT unit for Merdeka Madiun University, and always to check the degree of IT alignment with business activities to add value for more competitive organization.
\end{abstract}

Keywords: COBIT, Maturity Level, Governance

\begin{abstract}
Abstrak. Saat ini pemanfaatan teknologi informasi (TI) telah menjadi salah satu penunjang dalam keberhasilan sebuah organisasi, akan tetapi apabila organisasi tersebut tidak memiliki tata kelola TI yang baik maka TI hanya akan menjadi beban atau masalah baru pada organisasi. Oleh karena itu diperlukan sebuah tata kelola yang baik untuk mengatasi kesenjangan antara deskripsi dari sistem yang direkomendasikan dengan deskripsi yang diperlukan untuk implementasi sistem yang sebenarnya. Dan untuk mengukur sejauh mana keselarasan TI dengan kegiatan bisnis dan mengukur sejauh mana maturity level organisasi dapat dilakukan dengan menggunakan framework COBIT. Berkaitan dengan hal itu maka diperlukan sebuah unit TI di Universitas Merdeka Madiun, dan perlu untuk selalu ditinjau sejauh mana tingkat keselarasan antara TI dengan kegiatan bisnis organisasi untuk menambah nilai kompetitif.
\end{abstract}

Kata Kunci: COBIT, Maturity Level,Tata Kelola

\section{Pendahuluan}

Dewasa ini hampir semua bentuk organisasi, baik yang berorientasi terhadap laba maupun nirlaba menggunakan berbagai bentuk teknologi informasi untuk mendukung operasionalnya (Turban, McClean, \& Wetherbe, 2002). Hal ini disebabkan teknologi informasi telah menjadi fasilitator utama bagi kegiatan bisnis. Teknologi informasi berperan sangat signifikan di dalam memperoleh keuntungan kompetitif organisasi, meningkatkan efisiensi dan keefektifan, juga sebagai alat kolaborasi dan komunikasi (Jogiyanto, 2005).

Oleh karena itu, ada banyak alasan untuk percaya bahwa revolusi teknologi informasi (TI) secara radikal akan mengubah Universitas. Perubahan ini akan menyebabkan sudut pandang yang berbeda terhadap mahasiswa, staff pengajar, peran staff administrasi, kebutuhan dan harapan, dan cenderung menyebabkan perubahan besar dalam fungsi dan struktur 
Universitas (Gayle et al, 2003.). Meskipun TI merupakan sebuah kepentingan strategis, TI tetap mengandalkan manusia untuk penerapan yang efektif (Shin, 2001).

Di lain pihak, sumber daya informasi tersebar di seluruh bagian organisasi. Informasi dikirimkan dari satu bagian ke bagian lain di dalam organisasi, dan juga antar organisasi. Akibatnya, TI sebagai sumber daya fisik sistem informasi dan komponen sistem informasi lainnya dapat menjadi rentan terhadap bermacam-macam gangguan di berbagai tempat sepanjang waktu. Pada gilirannya hal ini akan mengancam keamanan sistem informasi itu sendiri. Kerentanan ini meningkat sejalan dengan berkembangnya pengelolaan data dan informasi dengan menggunakan jaringan (Turban, McClean, \& Wetherbe, 2002). Gangguan ini dapat berupa gangguan yang tidak disengaja maupun yang disengaja. Gangguan yang tidak disengaja dapat berupa kesalahan teknis, gangguan lingkungan, dan karena kesalahan manusia. Sementara gangguan yang disengaja dilakukan oleh manusia untuk tujuan tertentu (Jogiyanto, 2005).

Tidak dapat dipungkiri bahwa dewasa ini TI sangat berperan di dalam menunjang kegiatan akademik maupun non-akademik yang diselenggarakan oleh Universitas Merdeka Madiun (Unmer) di dalam menyelenggarakan pendidikan tinggi. Luasnya kampus Unmer dan lokasi unit yang tersebar dalam radius yang cukup luas sangat mempengaruhi tingkat aksessibilitas masing-masing unit atau lembaga yang ada di lingkungan kampus Unmer.

\section{Tinjauan Pustaka}

McCredie (2000) berpendapat bahwa sebuah organisasi akan ditinggalkan jika organisasi tersebut gagal dalam menyusun rencana strategis TI. Lederer dan Sethi (1988) mendefinisikan rencana strategis TI sebagai sebuah proses di mana organisasi menentukan portofolio aplikasi berbasis komputer untuk membantu dalam pencapaian tujuan bisnis. Ini terdiri dari strategi untuk perencanaan dan manajemen informasi, termasuk penggunaan dan fitur TI (Gallliers, 1995.). Dengan rencana strategis TI yang dikembangkan dengan baik dan sesuai dengan rencana strategis Universitas yang lebih luas, maka Universitas dapat menggunakan TI secara lebih kompetitif, mengidentifikasi keuntungan aplikasi IT, dan perkiraan kebutuhan sumber daya TI pada masa yang akan datang (Basu et al, 2002. ).

Pentingnya perencanaan strategis TI untuk keberhasilan sistem informasi pada Universitas disorot oleh banyak peneliti seperti Rowley et al. (1997), McCredie (2000), McRobbie dan Palmer (2001), Ishak dan Alias (2005), dan Ismail et al. (2007). Namun, hasil penelitian ini menunjukkan bahwa kebanyakan Universitas kurang memahami tentang bagaimana mengembangkan sebuah rencana strategis TI (Titthasiri, 2000). Hasil penelitian Semiawan dan Middleton (1999) mengungkapkan bahwa, sementara pengguna sistem informasi di beberapa Universitas di Indonesia cukup puas dengan layanan yang disediakan, analisis dokumen kebijakan menunjukkan bahwa perencanaan sistem informasi merupakan sebagian kecil dari perencanaan strategis Universitas. Demikian pula dengan, Ismail et al. (2007) mengungkapkan bahwa, meskipun Universitas mengatakan bahwa mereka telah menerapkan atau dalam proses pelaksanaan rencana strategis, analisis dokumen kebijakan dan wawancara menyatakan hal yang sebaliknya.

Namun, meskipun pentingnya rencana strategis TI yang komprehensif untuk keberhasilan implementasi TI, Hevner et al. (2000) memperingatkan bahwa banyak penggagas TI telah gagal karena adanya kesenjangan antara deskripsi dari sistem yang direkomendasikan dengan deskripsi yang diperlukan untuk implementasi sistem yang sebenarnya. Bahkan organisasi dengan kerangka TI yang solid pun gagal untuk mengimplementasikannya (Devlin dan Meyerson, 2001). Teo dan Ang, 2001; Nakatani dan Chuang, 2005). Ismail et al. (2007) menunjukkan bahwa untuk menjadi pelaksanaan rencana strategis TI yang sukses harus didukung oleh struktur TI, pendanaan, dan tata kelola yang solid, dan yang lebih penting adalah upaya terpadu dari semua pihak, terutama komitmen manajemen Universitas untuk merealisasikan rencana tersebut ke dalam sebuah tindakan. 


\section{Kondisi Sekarang dan Permasalahan}

Tujuan dari pengembangan dan implementasi teknologi informasi dan komunikasi (TI) Unmer selain untuk menjamin ketersediaan layanan jaringan kampus guna mendukung kegiatan akademik maupun non-akademik, dan sebagai gerbang diseminasi informasi mengenai Unmer kepada lingkungan luar, juga diharapkan dapat memberikan konstribusi terhadap tuntutan pengakuan global dan nasional terhadap perguruan tinggi.

Untuk melaksanakan berbagai Kegiatan Pengembangan dan implementasi TI di lingkungan Unmer, kegiatan-kegiatan dipisahkan atas tiga kegiatan utama, yaitu: 1). Pengembangan Jaringan; 2). Pengembangan Konten dan 3). Pengembangan Pusat Data. Pada tahap awal kegiatan difokuskan pada kegiatan pengembangan jaringan dan pengembangan konten, sedangkan kegiatan pengembangan pusat data baru pada tahap evaluasi kebutuhan dan mekanisme pengumpulan data. Selain ke tiga kegiatan tersebut, hal lain yang memerlukan perhatian adalah peningkatan Tata kelola TI dan penyiapan SDM TI.

Guna melaksanakan pengembangan dan implementasi TI, Hendaknya dibentuk sebuah unit khusus yang memiliki tugas dan wewenang untuk melaksanakan kegiatan pengembangan dan implementasi TI, Setelah kegiatan pengembangan dan implementasi tercapai fungsi akan ditambah untuk pengolahan data akademik, pengelola jaringan internet dan intranet Universitas. Rendahnya posisi strata TI dalam struktur tata kelola, merupakan masalah tersendiri dalam pengembangan dan implementasi TI.

Untuk mendukung terselenggaranya kegiatan, selain membentuk Unit Pengembangan TI perlu dilakukan pelatihan untuk meningkatkan kemampuan individu yang akan terlibat secara langsung dalam kegiatan ini, namun demikian rendahnya keterlibatan pengambil keputusan di tingkat fakultas, terbatasnya akses point dan jumlah tenaga terampil yang mengusai bidang TI menyebabkan kegiatan ini akan sedikit sulit untuk dilaksanakan sesuai dengan tenggang waktu yang diberikan.

Disamping permasalahan diatas, disisi lain ditemukan fakta-fakta dan persoalan lain yang terungkap, antara lain: (1) Rendahnya "aware" dan belum dipahaminya tanggung jawab dan peran masing-masing Fakultas/ Unit kerja dalam mendukung pelaksanaan layanan dan pengembangan TI. (2) Belum tersedianya Rencana pengembangan TI pada level strategis atau detil, termasuk roadmap dan portofolio proyek TI kedepan, rencana pengembangan TI hanya ada dan terbatas pada level Universitas. (3) Belum adanya buku pedoman yang mengatur prosedur operasi standar layanan pengaduan gangguan dan perbaikan. (4) Mekanisme penyelesaian konflik terkait perencanaan, pertukaran data dan penyediaan sumber daya belum ditetapkan. (5) Mapping kebutuhan arsitektur aplikasi belum mengacu kepada mapping kebutuhan infrastruktur. (6) Pengembangan Arsitektur Infrastruktur belum berorientasi pada pengadaan teknologi dan sistem informasi terbaru. (7) Masih rancu dan tidak jelasnya Tata kelola TI. (8) Terbatasnya SDM TI yang tersedia.

\section{Perbaikan dan Pemecahan Masalah}

Pengembangan dan Implementasi TI di Unmer terbagi dalam beberapa tahapan, yang terbagi dalam beberapa sub kegiatan, antara lain: pengembangan infrastruktur, pengembangan konten, dan pengembangan pusat data. Pengembangan infrastruktur jaringan difokuskan pada peningkatan aksessibilitas dari fakultas, lembaga, dan unit-unit yang ada dilingkungan Unmer dengan mengoptimalkan infrastruktur yang ada sehingga setiap unit, lembaga, dan fakultas dapat terhubung dengan jaringan internet dan intranet.

Mengacu pada permasalahan dan fakta-fakta yang terungkap dalam pengembangan dan implementasi TI diatas, agar tujuan pengembangan dan implementasi dapat berjalan sesuasi dengan sasaran, berbagai program dan kegiatan percepatan implementasi dan pengembangan perlu dilakukan. Adapun program dan kegiatan yang perlu segera dilaksanakan, antara lain: (1) Melaksanakan assesment menyeluruh terhadap keberadaan TI. (2) Merealisasikan segera struktur Tata Kelola TI, dan menyusun buku pedoman prosedur operasi standar layanan 
gangguan dan perbaikan. (3) Merealisasikan segera perbaikan dan peningkatan infrastruktur pendukung layanan TI, seperti sistem pengaman internal dan eksternal menara dan perangkat TI lainnya, dan pengoperasian sistem cadangan daya. (4) Merealisasikan segera kebutuhan peralatan kerja Helpdesk layanan TI.

Diharapkan dengan terlaksananya percepatan program dan kegiatan diatas, permasalahan dan fakta-fakta yang terungkap dapat segera diminimalisasi sehingga pengembangan dan implementasi TI dapat berjalan sesuai dengan rencana. Di bawah ini akan dibahas beberapa kegiatan yang dapat dilaksanakan segera.

\subsection{Self Assesment}

Selain pengakuan global, kredibilitas perguruan tinggi dalam perspektif nasional juga mempertimbangkan apakah perguruan tinggi terkait memiliki kredibilitas yang baik dalam perspektif industri partner atau masyarakat secara luas. Selain adopsi TI untuk layanan utama (seperti pendidikan, administrasi pendidikan, penelitian \& kemitraan dan manajemen organisasi) dan layanan pendukung, TI juga diadopsi dengan tipikal tambahan lainnya. Pertanyaan yang muncul adalah bagaimana merealisasikan keselarasan TI dengan kebutuhan Unmer. Bagaimana otoritas untuk sumberdaya, risiko, resolusi konflik, dan tanggung jawab untuk TI di-share di antara unit kerja, partner-partner organisasi, manajemen TI dan penyedia jasa. Termasuk juga di sini isu seleksi dan prioritisasi proyek-proyek TI.

Untuk menjawab, semua pertanyaan diatas, perlu dilakukan self assessment sehingga kita dapat mengetahui pada posisi mana Unmer berada. Self Assessment yang dilaksanakan dapat dilakukan dengan menggunakan instrumen yang sudah dikembangkan yaitu COBIT.

Control Objectives for Information and Related Technology (COBIT) untuk memenuhi kebutuhan pengelolaan dan pengendalian informasi dan terkait TI (Information System Audit and Control Foundation, 1998). COBIT adalah metodologi untuk mengelola dan mengendalikan informasi dan risiko serta kerentanan TI. COBIT menunjukan bahwa manajemen informasi dan TI yang efektif merupakan faktor yang sangat penting bagi keberhasilan dan kelangsungan hidup organisasi (Lainhart, 2000). COBIT juga merupakan salah satu kerangka kerja ITG yang penting dan merupakan tools yang memungkinkan seorang manajer TI untuk berkomunikasi dan menjembatani kesenjangan antara risiko bisnis, kebutuhan kontrol, penciptaan nilai dan masalah teknis (Lainhart, 2000; Bodnar, 2003; Hardy, 2006; dan Williams, 2006 ). COBIT diciptakan oleh Information System Audit and Control Association (ISACA), dan IT Governance Institute (ITGI) pada tahun 1992. Edisi pertama dari COBIT diterbitkan pada tahun 1996, edisi kedua 1998, edisi ketiga tahun 2000, dan edisi online pada tahun 2003. Dan edisi keempat diterbitkan pada tahun 2005.

Selain itu, untuk mengetahui daya dukung dan ketersediaan infrastruktur TI yang ada saat ini perlu juga dilaksanakan Re-assessing the Existing Network and Identifying Customer Objectives yang dapat dilakukan secara bersama antara Unit TI dan pengembang software atau pihak lainnya.

\subsection{Struktur Tata Kelola TI}

Permasalahan umum yang terjadi pada Tata Kelola TI, umumnya disebabkan beberapa hal, antara lain: (1) Posisi TI memiliki strata dibawah Unit lainnya. (2) Tidak ada standarstandar TI (3) SDM yang sangat terbatas.

Untuk dapat merealisasikan IT Leadership, salah satu cara adalah merealisasikan fungsi komite TI. Pendekatan ini dapat menutupi permasalahan utama sulitnya mereposisi TI pada posisi yang paling ideal, dengan demikian rancangan tata kelola TI yang diusulkan adalah sebagai berikut: (1) Komite Pengarah TI, peran utamanya menetapkan Renstra TI dan Cetak Biru TI. (2) Komite Kerja TI, peran utamanya sebagai penyusun kebijakan TI. (3) CIO (Chief Information Officer). Keberadaan CIO ditujukan untuk memastikan kepemimpinan TI institusi yang memadai dalam mengeksekusi berbagai agenda strategis TI dalam rangka mendukung 
obyektif strategis institusi. (4) Struktur Internal Organisasi TI, dalam hal ini peningkatan tugas dan fungsi Unit TI. (5) Staff SI/TI dilingkungan Fakultas/Unit Kerja lainnya.

\subsubsection{Komite Pengarah TI}

Peran komite pengarah TI adalah : (1) Menetapkan Rencana Strategis TI dan Cetak Biru TI . (2) Mereview dan memberikan persetujuan Rencana TI Universitas (khususnya yang bersifat strategis) yang mengakomodir kepentingan seluruh stakeholder melalui penetapan cetak biru TI. (3) Melakukan evaluasi secara berkala atas keberjalanan inisiatif TI strategis dan ketercapaian benefit. (4) Menetapkan Kebijakan dan SOP TI yang telah direview oleh Komite Kerja TI.

Struktur keanggotaan Komite Pengarah IT antara lain: (1) Ketua: Rektor (2) Anggota: (a) Pembantu Rektor I (b) Pembantu Rektor II (c) Pembantu Rektor III.

Komite Pengarah TI bertemu minimal 6 bulan sekali, selain pertemuan on demand yang dapat diselenggarakan sesuai kebutuhan berdasarkan permintaan dari Rektor, Pembantu Rektor atau Komite Kerja TI. Topik yang menjadi pembahasan dalam pertemuan Komite Pengarah TI di antaranya adalah: (1) Review dan persetujuan Rencana TI Strategis (dan perubahannya jika ada) yang akan ditetapkan oleh Rektor. (2) Review dan persetujuan Rencana TI Tahunan (dan perubahannya jika ada) yang akan ditetapkan oleh Rektor. (3) Evaluasi program TI strategis dan pencapaian target benefitnya.

\subsubsection{Komite Kerja TI}

Peran Komite Kerja TI adalah: (1) Melakukan review akhir atas Rencana Strategis TI, Cetak Biru TI, Rencana Tahunan TI dan kebutuhan aplikasi bisnis oleh seluruh unit kerja. (2) Melakukan evaluasi berkala atas dukungan TI kepada seluruh stakeholder. (3) Menjadi clearing house bagi penyelesaian masalah-masalah eksekusi program-program TI, khususnya antara Unit TI dan unit-unit kerja. (4) Melakukan review akhir atas kebijakan dan SOP TI yang disiapkan oleh Unit TI, untuk selanjutnya akan ditetapkan oleh Komite Pengarah TI atau Rektor.

Struktur keanggotaan Komite kerja TI antara lain: (1) Ketua: Pembantu Rektor I (2) Anggota: (a)Kepala Unit TI (merangkap sekretaris) (b) Perwakilan UPT (c) Perwakilan BiroBiro (d) Perwakilan Fakultas/Lembaga/Badan-Badan (e) Perorangan karena kepakaran.

Komite Kerja TI bertemu minimal 3 bulan sekali, selain pertemuan on demand yang dapat diselenggarakan sesuai kebutuhan berdasarkan permintaan dari Wakil Rektor I, Unit TI atau unit kerja terkait. Topik yang menjadi pembahasan dalam pertemuan Komite TI di antaranya adalah: (1) Review permintaan kebutuhan akan sistem TI oleh bagian bisnis lain kepada TI, khususnya untuk permintaan yang bersifat strategis dan akan memerlukan sumberdaya yang signifikan. (2) Evaluasi rutin seluruh implementasi TI yang telah direncanakan sebelumnya. (3) Evaluasi rutin indeks kepuasan stakeholder atas layanan TI.

\subsubsection{Pembentukan Unit TI Unmer}

Perlu segera dibentuk Unit khusus yang bertanggung jawab penuh terhadap pelaksanaan dan penerapan TI di lingkungan Unmer. Selain itu perlu dipetimbangkan dari awal adalah apakah diperlukan staff TI di tiap fakultas atau unit kerja lain? Dan bagaimana mekanisme pertanggungjawaban dan koordinasi antara Unit Pengelola TI dengan staff TI di tiap unit kerja tersebut?

Mengacu pada model pengembangan dan implementasi TI serta tugas dan fungsi Unit TI, maka struktur Unit TI ke depan di usulkan sebagai berikut : (1) Kepala Unit TI, dibantu oleh Tata Usaha (2) Divisi Pengembangan Sistem, dengan tugas dan fungsi melaksanakan pengembangan aplikasi, pemberian technical. (3) Divisi Infrastruktur Jaringan dan Telekomunikasi. (4) Divisi Layanan Pengguna. 
Setelah dilakukan estimasi kebutuhan SDM TI dalam struktur organisasi TI, cetak biru Tata Kelola TI juga harus menetapkan program pengembangan SDM TI. Program pengembangan SDM TI dapat merujuk pada value chain kompetensi TI. (1) Pengembangan aplikasi-aplikasi, baik secara inhouse atau kerjasama dengan pihak ketiga. (2) Pemberian technical support atas aplikasi atas eskalasi dari IT Helpdesk. (3) Pemeliharaan aplikasi dan perubahannya. (4) Pengelolaan rutin infrastruktur jaringan, server dan data center. (5) Pengelolaan keamanan TI jaringan. (6)Pengelolaan backup data aplikasi kritikal. (7) Pelaksanaan Technical Support atas infrastruktur atas eskalasi dari IT Helpdesk. (8) Penyelenggaraan training TI untuk civitas, baik yang mendukung kurikulum atau di luar kurikulum. (9) Pelaksanaan fungsi IT Helpdesk. (10) Pelaksanaan Desktop Services untuk pengguna.

\subsubsection{Staff TI dilingkungan Fakultas atau Unit Kerja lainnya}

Staff TI mempunyai peran antara lain: (1) Pelaksana IT Helpdesk tingkat Fakultas atauUnit Kerja. (2) Penghubung IT Helpdesk Universitas.

Staff TI bertemu minimal 3 bulan sekali, selain pertemuan on demand yang dapat diselenggarakan sesuai kebutuhan. Melakukan tugas dan fungsi pengendalian jaringan di Unit Kerja. Melaporkan dan mencatat gangguan yang terjadi baik pada sisi Fakultas maupun Universitas.

\section{Kesimpulan}

Perlu segera dibentuk sebuah tim khusus yang tidak bersifat adhoc khusus untuk mengelola sistem informasi yang digunakan pada Unmer Madiun. Agar tata kelola sistem informasi yang ada dapat menunjang kegiatan Institusi untuk mencapai tujuan utama dari Unmer Madiun. Pemanfaatan COBIT untuk menilai tingkat kematangan Universitas dapat digunakan sebagai acuan untuk mengatasi kesenjangan antara deskripsi dari sistem yang direkomendasikan dengan deskripsi yang diperlukan untuk implementasi sistem yang sebenarnya.

\section{Referensi}

Basu, V., Hartono, E., Lederer, A.L. and Sethi, V, 2002, The impact of organizational commitment, senior management involvement, and team involvement on strategic information systems planning, Information and Management, Vol. 39 No. 6, pp. 513-24.

Bodnar, G. 2003, IT governance, Internal Auditing, Vol. 18 No. 3, p. 27.

Devlin, M. and Meyerson, J. 2001, Strategic and financial planning for information technology in higher education, Forum Strategy Series, Vol. 3, pp. 127-40.

Galliers, R.D, 1992, Choosing information systems research approaches, Galliers, $R$. (Ed.), Information Systems Research - Issues, Methods and Practical Guidelines, Blackwell Scientific Publications, Oxford.

Gayle, D.J., Tewarie, B. and White, A.Q. Jr, 2003, Governance in the twenty-first century university: approaches to effective leadership and strategic management, ASHE-ERIC Higher Education Report, Vol. 30 No. 1, pp. 1-132.

Hardy, G. 2006, Using IT governance and COBIT to deliver value with IT and respond to legal,regulatory and compliance challenges, Information Security Technical Report, Vol. 11 No. 1, pp. 55-61.

Hevner, A.R., Bern, D.J. and Studnicki, J. 2000, Strategic information systems planning with box structures, Proceedings of the 33rd Annual Hawaii International Conference on System Sciences, Vol. 1 No. 4, pp. 101-20. 
Ishak, I.S. and Alias, R, 2005, Designing strategic information systems planning methodology for Malaysian institutions of higher learning, Issues in Information Systems, Vol. VI No. 1, pp. 325-31.

Ismail, N.A., Raja Mohd Ali, R.H., Mat Saat, R. and Hsbollah, H, 2007, Strategic information systems planning among public institutions of higher learning in Malaysia, CampusWide Information Systems, Vol. 24 No. 5, pp. 331-41.

Information Systems Audit and Control Foundation (1998), Control Objectives for Information and Related Technology (COBIT), ISACF, Rolling Meadows, IL.

Jogiyanto, Prof. Dr, 2005, Sistem Teknologi Informasi. Yogyakarta: Penerbit Andi

Lainhart, J.W. IV, 2000, COBIT: a methodology for managing and controlling information and information technology risks and vulnerabilities, Journal of Information Systems; Supplement, Vol. 14 No. 1, pp. 21-5.

Lederer, A.L. and Sethi, V, 1988, The implementation of strategic information system planning methodologies, MIS Quarterly, Vol. 123, pp. 445-61.

McCredie, J.W, 2000, Planning for IT in higher education: it's not an oxymoron, Educause Quarterly, Vol. 4, pp. 14-21.

McRobbie, M.A. and Palmer, J.G, 2001, Strategic and financial planning for information technology in higher education, Forum Strategy Series, Vol. 3, pp. 127-40.

Rowley, D.J., Lujan, H.D. and Dolence, M.G, 1997, Strategic Change in Colleges and Universities, Jossey-Bass, San Francisco, CA.

Shin. N, 2001, The impact of information technology on financial performance: the importance of strategic choice, European Journal of Information Systems, Vol. 10, pp. 227-36.

Teo, T.S.H. and Ang, J.S.K. 2001, An examination of major IS planning problems, Information Management, Vol. 21, pp. 457-70.

Turban, Efraim; McLean; Wetherbe; \& James, 2002, Information Tehcnology for Management: Transforming Business in The Digital Economy, USA: John Wiley

Williams, P. ,2006, A helping hand with IT governance, ComputerWeekly, Vol. 19, September, pp. $26-7$. 